\title{
The Portonaccio Sarcophagus' Roman Cavalry Charge: New Insights (and a Postscript on the Film Gladiator's Clash with the Germans)
}

\author{
By Robert B. Kebric*
}

The Portonaccio Sarcophagus portrays on its front side one of the most realistic engagements between Roman cavalry and barbarians during the Imperial period. The Sarcophagus was fashioned, it appears, for Marcus Aurelius' general, Aulus Julius Pompilius. It displays a fierce encounter with Germans along the Danube at about the same time that the reconstructed cavalry charge shown in the popular film, Gladiator (2000), has General Maximus destroying hoards of Germans in 180 A.D. While the Sarcophagus was subject to symbolism, space restrictions, and artistic convention, there remains no doubt that it otherwise embodies the features of an actual Roman battle and reveals some aspects of combat that have previously been overlooked. In the center of the action, Pompilius and his lieutenant wield "Battle Truncheons," deadly "clubs" that do not seem to have an exact parallel in other depictions of Roman cavalry in action. There also appears to be a coordination between cavalrymen and their accompanying foot soldiers who are working together in cramped quarters to destroy barbarians as efficiently as possible in a "Hammer and Slash" type of combat. The Sarcophagus iconography also clearly demonstrates just how incorrectly the cavalry scene in Gladiator was recreated for modern film audiences.

In the stirring opening battle scene of the Academy-Award winning epic, Gladiator (2000), Maximus leads his Roman cavalry through a burning forest in a dramatic charge. In the rear guard action depicted in the film, Marcus Aurelius' "greatest general" and his thundering hoard ride roughshod over the hapless Germans, who, surprised by the unexpected maneuver, fall before them like heavy matchsticks.

Contrary to the film's spectacular but largely fictitious recreation of a Roman cavalry charge along the Danube in 180 B.C, there is a mostly authentic portrayal of a similar engagement between Marcus Aurelius' cavalry and Germans on the Portonaccio Sarcophagus. The intense, bloody, and savage melee is vividly sculpted on the front panel of the Sarcophagus, now in the Palazzo Massimo alle Terme in Rome. It, too, depicts a charge of Roman horsemen-- this one in the company of foot soldiers-- against Germans, but it is fought in quarters so close that one wonders how anyone could have emerged unscathed (Figure 1). A final expression of anguish marks barbarian faces everywhere as they seem to succumb as readily as those in the film before the withering onslaught of swords, lances-- and, most interesting, long "battle sticks" wielded by a Roman general and his lieutenant.

*Senior Professor of History, University of Louisville, USA.

https://doi.org/10.30958/ajhis.1-3-1

doi=10.30958/ajhis.1-3-1 
Figure 1. The Portonaccio Sarcophagus Cavalry Battle Scene (Palazzo Massimo Alle Terme Museum, Rome)

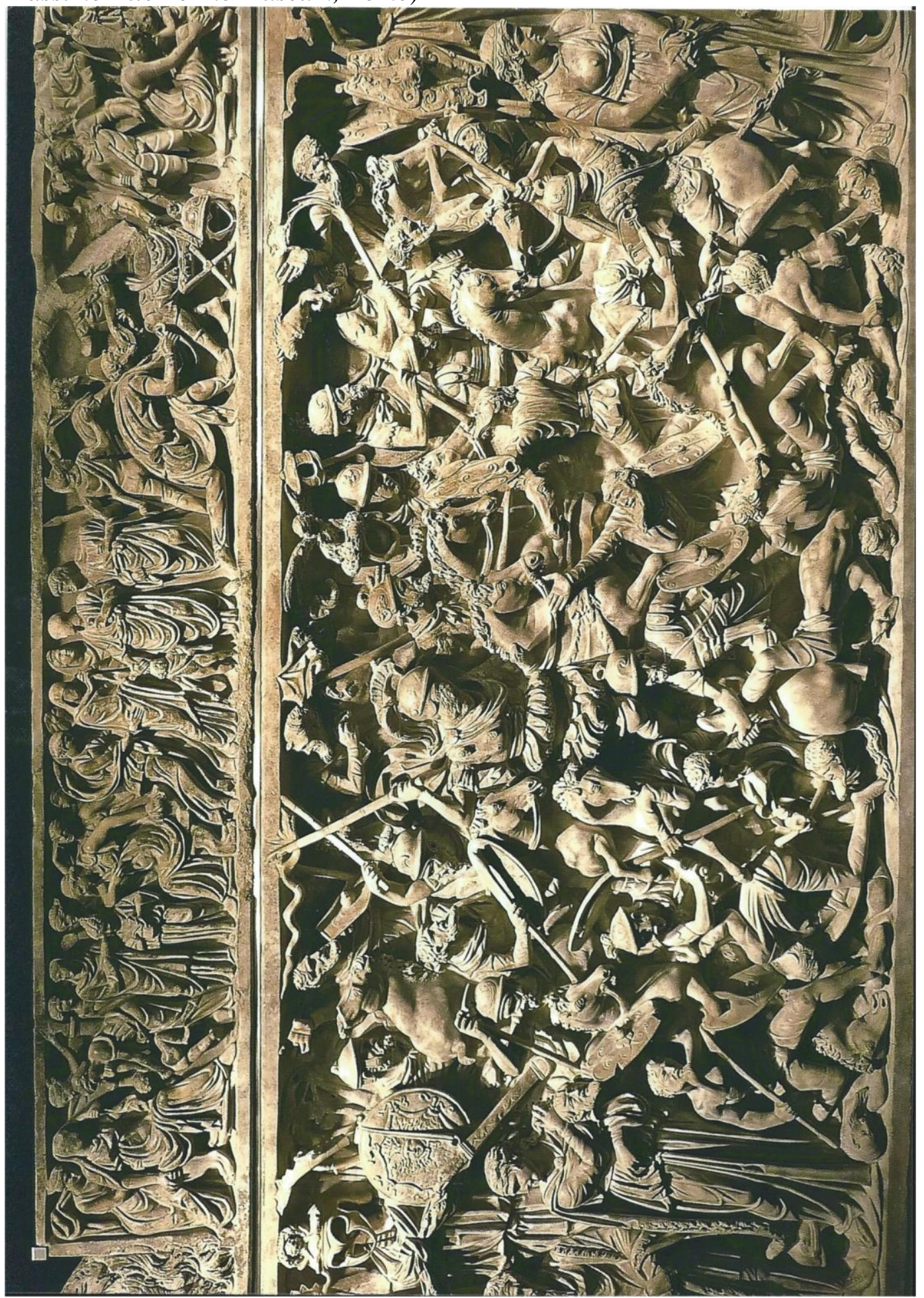

It is this more historically correct representation of a Roman cavalry charge that is the focus of the present study, although it had started out as an inquiry into the accuracy of the aforementioned battle scene in Gladiator. The 
results of that exercise on movies and history were delivered in a paper at the July, 2014, Atiner International Conference on History and Archaeology in Athens, and the on-line version is available on the Atiner website. That same study had unexpectedly uncovered some apparently overlooked aspects of the Roman military that could only be given scant attention in a Conference paper whose topic had already been announced as Gladiator. Here, however, the roles are reversed, and the new revelations about the Roman military discovered on the Sarcophagus panel are the central concern.

The Portonaccio Sarcophagus is thought to have been fashioned for (but never finished or used by) Aulus Julius Pompilius, ${ }^{1}$ who, like Maximus in Gladiator, served Marcus Aurelius at about the same time in the same general area. The emperor had placed young Pompilius in command of two legions, the I Italica and the IIII Flavia Felix ${ }^{2}$, which included cavalry squadrons, on the Danube frontier in Lower and Upper Moesia during the war against the Marcomanni (172-175 A.D.). The Palazzo Museum's own descriptive narrative accompanying the Sarcophagus display also identifies the emblems of these two legions, the wild boar's head (I Italica) and the eagle (IIII Flavia), at the very top of the battle scene, just below the Sarcophagus lid- making the connection to Pompilius an even firmer one. It is certainly unlikely that another general would have been leading these same squadrons at this very moment and be represented doing so on such a worthy casket. The highsnouted, curled lipped boar $^{3}$ appears at the top of the general's raised weapon in the space precisely between the crossed weapons of him and his lieutenant (an eye-catching place to locate the creature). With the larger, open-winged eagle perched on the opposite side peering directly at Pompilius, also from beneath the Sarcophagus lid, the two legionary symbols appropriately frame their general in the central scene (Figure 2).

\footnotetext{
All photos are by the author.

${ }^{1}$ Antony Birley, Marcus Aurelius: A Biography (New Haven and London: Yale University Press [revised edition], 1987), 176, identifies him as Julius Pompilius Piso; also cited elsewhere as Aulus Julius Pompilius Piso.

${ }^{2}$ For the name IIII Flavia Felix, see Lawrence Keppie, The Making of the Roman Army: From Republic to Empire (New York, N.Y.: Barnes \& Noble Books ([reprint], 1994), 206 and 214. ${ }^{3}$ The boar appears to have had his once threatening tusk broken off but otherwise closely resembles heraldry illustrations. The Palazzo Museum's experts are convinced it is the boar. Of particular usefulness for comparison are the line drawings \#s 2, 3, and 9 on the top row of illustrations at "Images for wild boar heraldry," when "Googled" under that entry.
} 
Figure 2. The Wild Boar Symbol of "Legio I Italica" (Left), and Eagle of IIII "Flavia" (Right) Are Displayed just Below the Lid of the Sarcophagus, Framing Pompilius Charging on Horseback in the Center. The Face of the General Was Never Finished

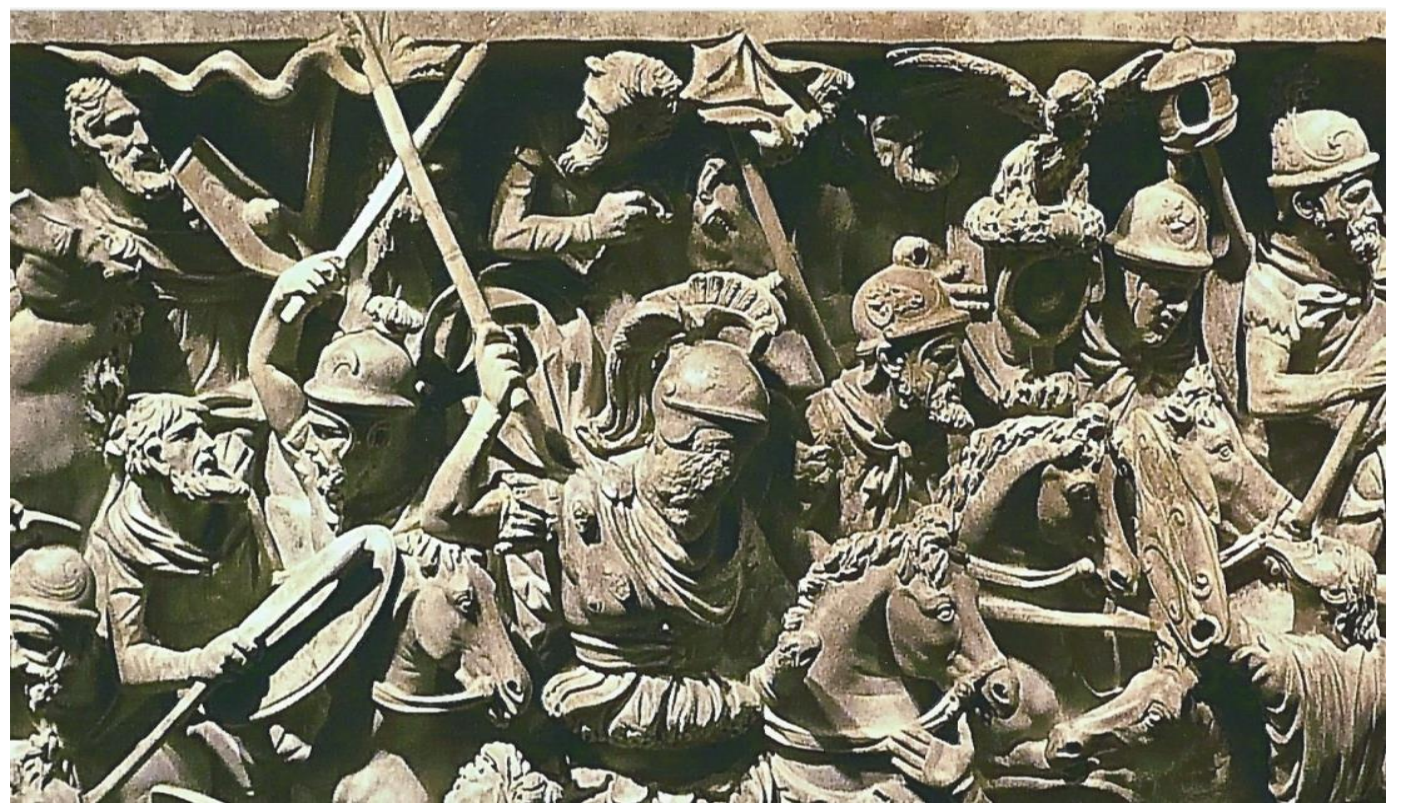

The same placard in the Museum also states that the Sacophagus' sculptural decoration was "inspired" by scenes from the now fallen Antonine Column. Indeed, their similar appearance, and that of other contemporary sculpture relating to Marcus Aurelius, supports a dating to the same period. For instance, a relief in the Palazzo dei Conservatori (Capitoline Museums) portrays Marcus as he proceeds on horseback among his general(s) and praetorians, showing clemency to captured barbarians (Figure 3). His general's cloak (Paludamentum) flowing airborne behind him is so like the one Pompilius is wearing on the Sarcophagus relief that the same artist(s) could have sculpted both (Figures 4-5). 
Figure 3. Relief from a Monument in Honor of Marcus Aurelius: Imperial Clemency. Palazzo Dei Conservatori (Capitoline Museums, Rome)

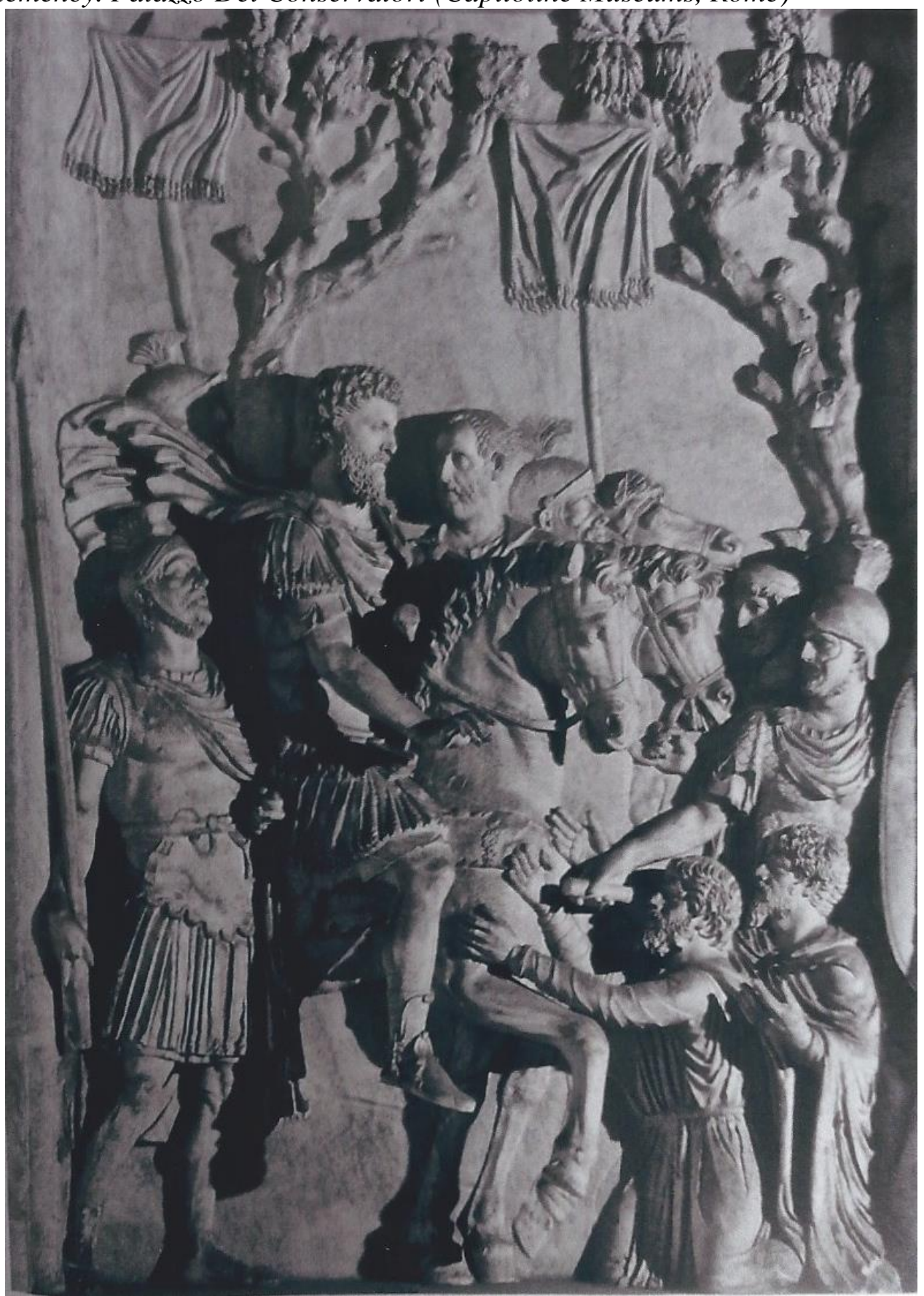


Figure 4. The Similarly Sculpted General's Cloak (Paludamentum) of Pompilius

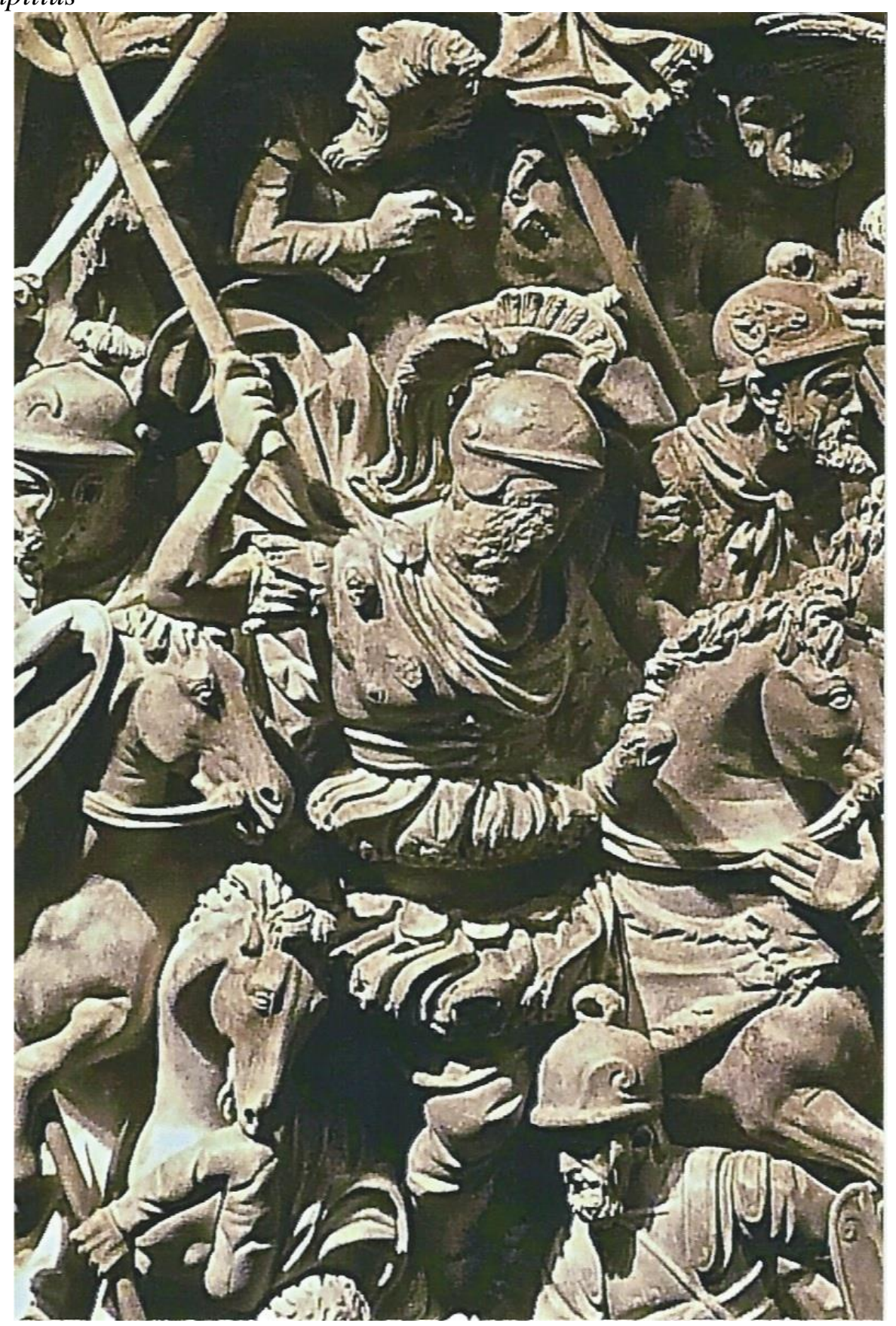


Figure 5. The Similarly Sculpted General's Cloak (Paludamentum) of Marcus Aurelius

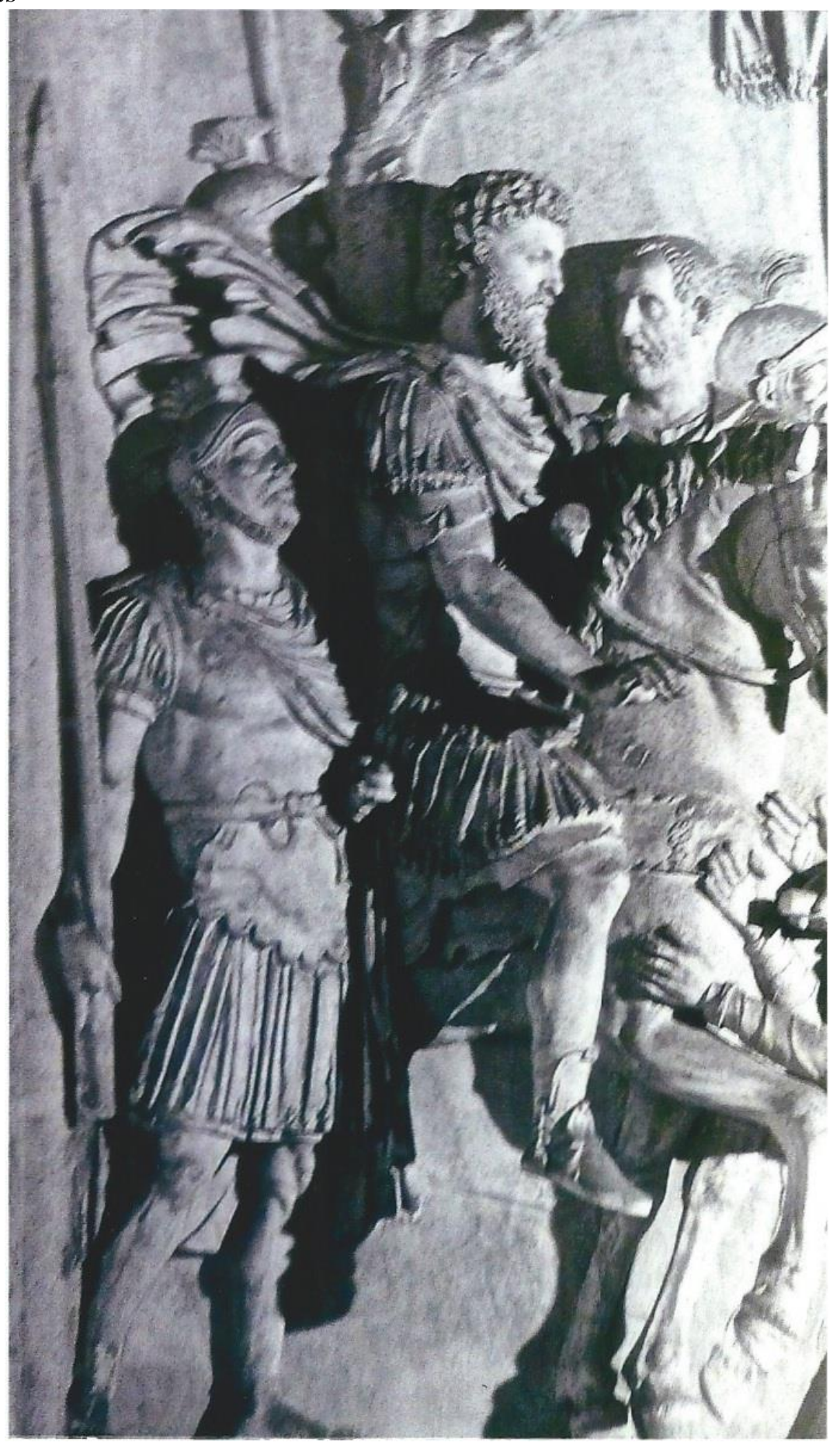

The Aurelian Column in the Piazza Colonna at Rome would also soon be completed (c.193 A.D.), and it depicted the same wars. Its extensive sculpture work may already have been underway when the Sarcophagus was being fashioned. 
Oddly, the military iconography on the Portonaccio Sarcophagus is conspicuously missing from modern handbooks on the Roman army. ${ }^{1}$ Its authenticity does not appear to be in doubt - and both its subject matter and representation of the battle appear almost unique among relics from this period. The main scene may have been idealized for purposes of composition and theme, and symbolism and artistic license have understandably been employed to please an obviously prominent client: This was, after all, going to be Pompilius' final resting place. Artists, themselves, are also known to have taken liberties. For example, some suggest that the pointed-helmeted, ankle length skirted "Levantine" archers in mail armor on Trajan's column are actually artistic composites. So, too, the frieze on the Sarcophagus' lid appropriately favors the nobility of the general's family, his own clementia (akin to that Marcus Aurelius is exercising in the aforementioned relief in the Piazza dei Conservatori in Figure 3), and other qualities one would expect on such a monument.

Even with such embellishments, however, there appears to be little fundamentally wrong with the central battle scene, and the lack of attention it has received seems curious at best. The detail is just too specific not to have been based on actual illustrations and models. Aside from the need to adjust proportions of horses (the central group is reminiscent of ones on merry-gorounds, but others are in realistic postures of intense action or have fallen) and individuals to fit the tight space on the Sarcophagus, the details are so specific that it is almost as if the artist had been there. While it may be the result of an eyewitness account(s), perhaps that of Pompilius himself, the tradition of the campaign artist is a long one. There is no reason that Roman emperors and generals would not have taken artists with them to recapture their glory in battle (one wonders if artist renderings did not originally accompany Caesar's war commentaries) - especially if the artist were subsequently to paint or sculpt a battle scene such as the one on the Sarcophagus. This seems particularly noticeable in the use of the previously mentioned "battle sticks," wielded by Pompilius and his officer. The unusual weapon must have been the one Pompilius used on this occasion-- a personal favorite. Now he would be shown for all eternity with it raised and ready to smash barbarian skulls. If not, he would have been depicted using the standard, elongated spatha cavalry sword-- or the lance that others in his company employ. The "battle sticks" are no mistake, and, as noted before, both his and his lieutenant's form a crossing pattern close to the middle of the action with the Legio's boar's head symbolically appearing between them at the top.

Interestingly, among the Romans engaged on the Sarcophagus, no one is shown with a spatha, a sword usually about three feet in length that had replaced the shorter military gladius for mounted combat. It spared a cavalryman having to lean down from his horse to strike an enemy foot soldier

\footnotetext{
${ }^{1}$ Although it attracted enough attention for the makers of another film on Rome, A Funny Thing Happened on the Way to the Forum (1966), to parody it in the end credit art where the chief figures even move their weapons.
} 
and chance falling off his saddle (no stirrups) as he rode swiftly by. That detail would also appear to make this a more authentic representation of an actual cavalry charge because, if it had been left to the artist, he would probably have armed the men not with "battle sticks" but the kind of weapons everybody likes to see in combat: swords and lances. On the Sarcophagus, however, as his cavalry engages the Germans with lances, Pompilius and his lieutenant employ "battle sticks," a weapon that is neither mentioned nor described in standard texts on Roman weapons.

These "battle sticks" can only be classified as a form of "club." However, in what is apparently the fullest discussion of "clubs" in Roman warfare, Michael P. Speidel also overlooks them-- even though he is one of the few to mention the Portonaccio Sarcophagus. He also provides two small illustrations from it, but the discussion is centered on German horse stabbing and hewering weapons. ${ }^{1}$ It is difficult to believe that these "battle sticks" have not been noticed before, but as of this writing, I have not been able to locate anything about them - or what the Romans even called them. Consequently, until more is known, I will name them "Battle Truncheons" - most appropriate, perhaps, because the latter word was once used to describe a fragment of a spear (i.e. lance) shaft used as a weapon. From a distance, some might mistake the "Battle Truncheons" wielded by Pompilius and his lieutenant as such remnants since there are many lances (at least two of them are broken, but this may be the result of later damage to the Sarcophagus) at work in the scene. In such a frantic encounter, the chances of breaking one's lance were very high and with no opportunity to secure another weapon, using the remainder as a club would only be natural. Upon closer inspection (Figure 6), however, it is unmistakably clear that the weapons of Pompilius and his lieutenant are not broken lances; nor are they clubs such as the one held by the German being attacked by Pompilius' lieutenant (Figure 7). They also display no similarity to the "clubs" described as being "equipped with heavy iron knobs" in one of the rare mentions in ancient literature of club weapons used by Romans-- when Constantine's soldiers are later reported ${ }^{2}$ to have employed them with devastating effect against Maxentius' heavy cavalry at the Battle of Turin in 312. In fact, the "Battle Truncheons" on the Portonaccio Sarcophagus are not clubs in the conventional sense at all, because the general impression of a "club" is more like the one already mentioned in the hand of the German facing Pompilius' lieutenant. That crude club is narrow at the base and thickens almost like a baseball bat as it progresses to the top. The German holds it midway at the point where it begins to increase in size and apparently becomes the most effective weapon.

\footnotetext{
${ }^{1}$ See Michael P. Speidel, Ancient Germanic Warriors: Warrior Styles from Trajan's Column to Icelandic Sagas (London and New York: Routledge, 2004), 87-97; also, Figures 17.4, and 18.2, for illustrations of his discussion of the Portonaccio Sarcophagus. One wonders, however, about Speidel's comment that the battle scene on the Sarcophagus shows an equal number of Germanic and Roman horsemen and foot soldiers engaged in combat - which it clearly does not.

${ }^{2}$ C.E.V. Nixon and Barbara Saylor Rodgers, eds., Panegyrici Latini: Nazarius, Panegyric of Constantine 4.22-24.3ff. (Berkeley and Los Angeles: University of California Press, 1994).
} 
Figure 6. Close Up of "Battle Truncheons" in the Hands of Pompilius and his Lieutenant

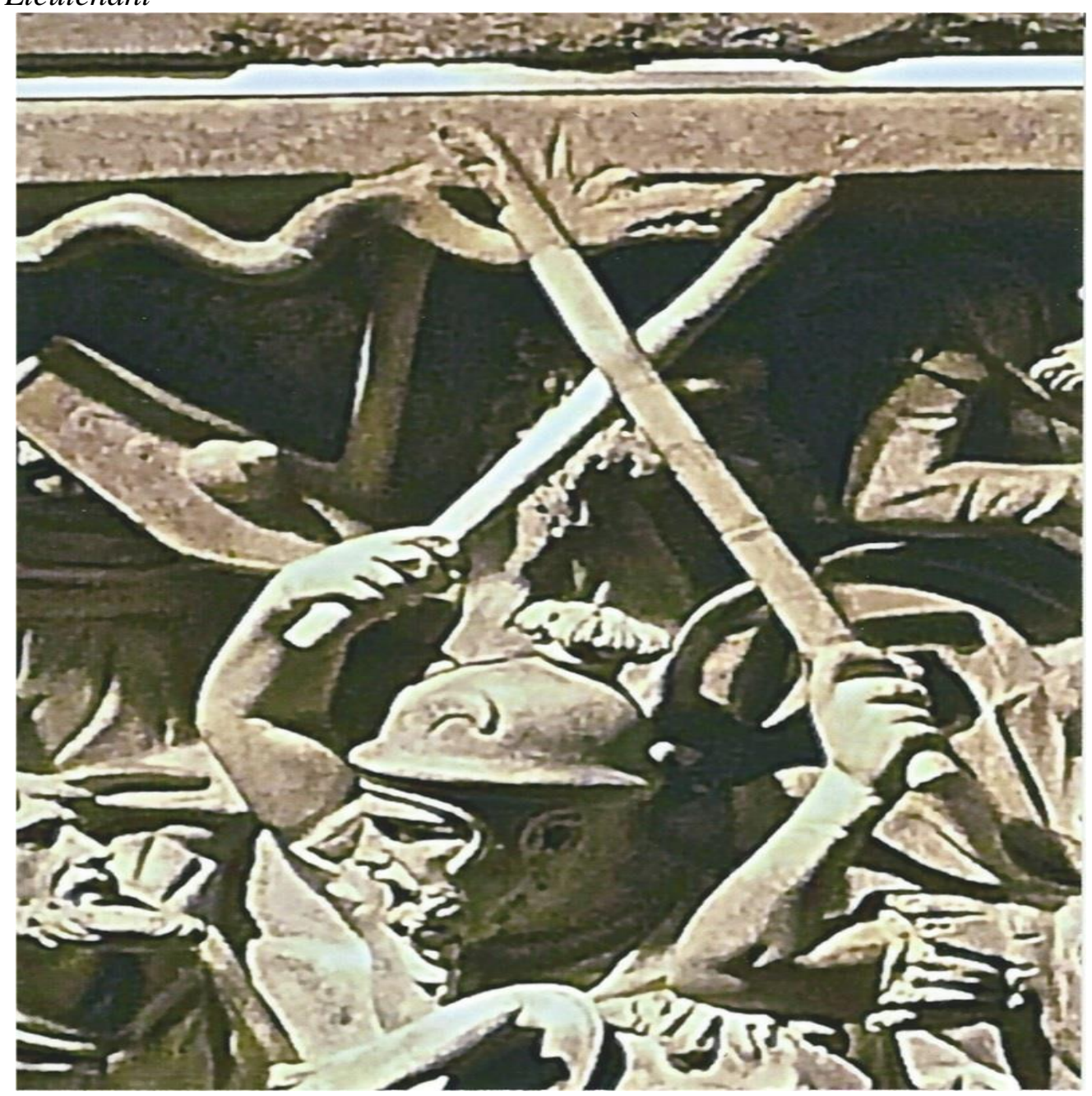


Figure 7. A German Opponent with a Conventional War Club in Hand

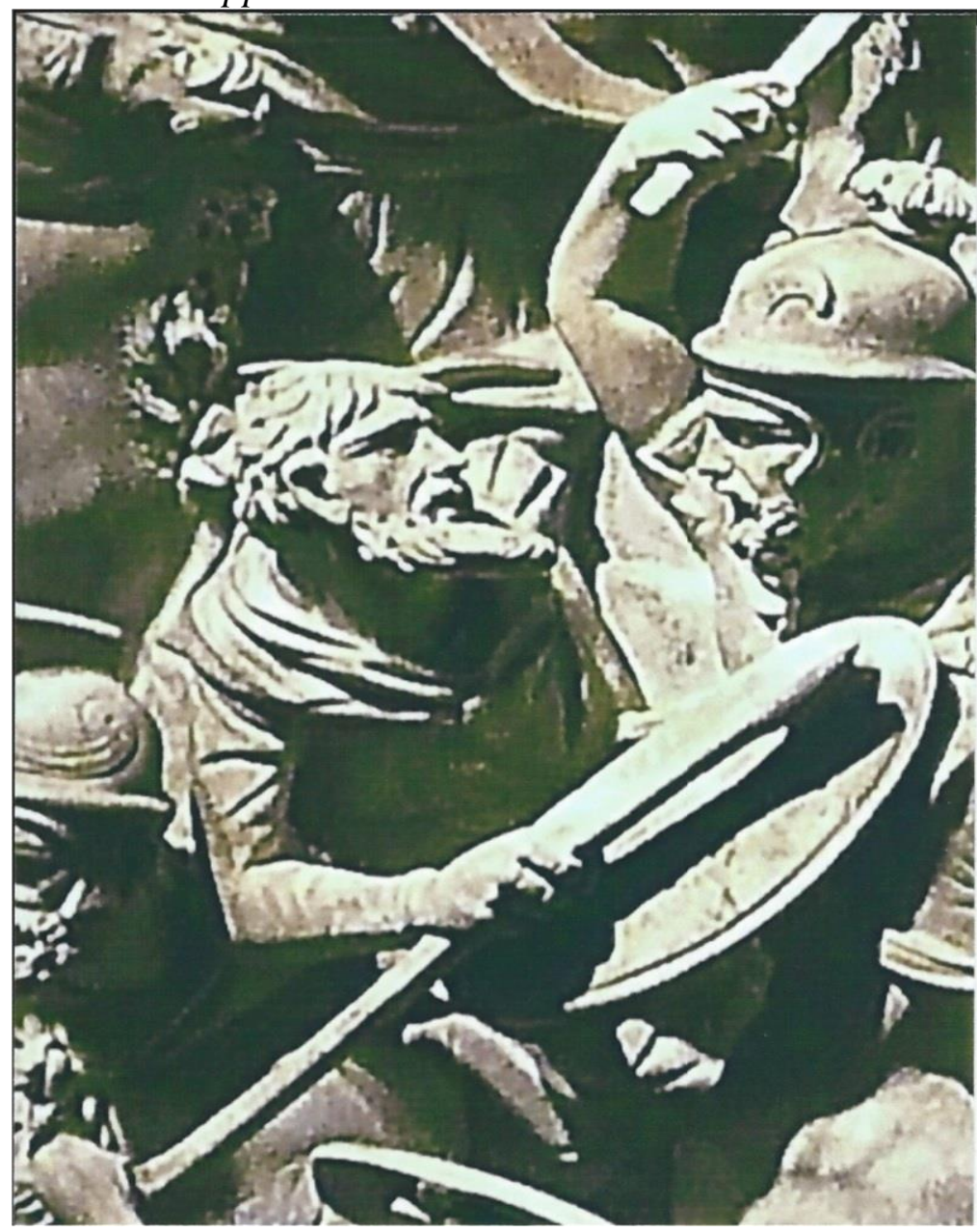

The "Battle Truncheons" Pompilius and his lieutenant wield, however, appear to have a handgrip, indicated by the way that Pompilius holds his at its base with his index finger opened over the top edge of it for a tighter grasp. ${ }^{1}$ If there were no grip there, his fingers would be closed all together like those of his fellow horsemen who hold lances. In fact, no one can hold a lance or a sword in the way Pompilius holds his Truncheon-- nor could his lieutenant hold any other type weapon but a Truncheon with his hand positioned in the backward manner that it is-- and still be able to strike downward on an enemy's head. $^{2}$

\footnotetext{
${ }^{1}$ As may be observed in the photos, Pompilius' hand was once broken at the wrist, but the repair does not interfere in any way with his grip on the Truncheon handle.

${ }^{2}$ In contrast, note the natural position of the raised sword hand on the mounted figure just to the central individual's right on the front of the Ludovisi Sarcophagus. See, also, the soldier with raised sword hand who is directly beneath the legs of the central figure's horse. The hand on a fragment of a "Roman Marble Lifesize Forearm Holding a Baton," is similarly positioned like those of Pompilius and his lieutenant-- though apparently the baton shown in this case is not a weapon but a symbol of military authority. Nonetheless, as a weapon, it would be held the same way, as seen from the photo below. Interestingly, a soldier at the far right end (from a viewer's perspective) of the same Ludovisi Sarcophagus appears to be holding something that
} 
Along the length of Pompilius' long, rounded Truncheon, are also places where the sculpture has been broken and mended. There is at least one clear previous break on his lieutenant's weapon as well. ${ }^{1}$ As repaired, both their weapons extend about the length of a spatha, which should not be surprising since sword and Truncheon had to be long enough to reach victims from horseback. Unfortunately, it is impossible to know how these Truncheons ended because both are broken or chipped at the top. Marks on the Sarcophagus lid above the lieutenant's weapon would indicate that it originally extended in front of it, just as Pompilius' badly chipped Truncheon continues to do so. It remains unclear whether or not they were tipped with metal, but it is more than likely that they ended with iron finals because if they did not, the weapons would have been less effective and unbalanced. They also do not appear to be substantial enough to have supported the kind of heavy "iron knobs" Constantine's clubs are said to have sported-- but their shafts would have to have been strong enough not to break from the intense force of a single downward stroke meant to kill or disable. Perhaps they had an iron core-- but one not so heavy that they could not be wielded with one hand, as Pompilius and his lieutenant appear to do with ease.

These "Battle Truncheons," then, were specially crafted weapons, and no argument can successfully dismiss them as makeshift creations, pieces of broken lances, or unfinished work by the sculptor(s), who ultimately was going

looks to be another type of carefully crafted "club." It bares no resemblance to a "Battle Truncheon," but the positioning of the soldier's hand even while the "club" rests on his shoulder, is also instructive.

(Photo below is author's own photo taken from catalogue of Royal-Athena Galleries, which offered the marble piece for sale at www.royalathena.com/PAGES/RomanCatalog/Marble /BPPP14.html. I know of no other publication of, or reference to, the item.)

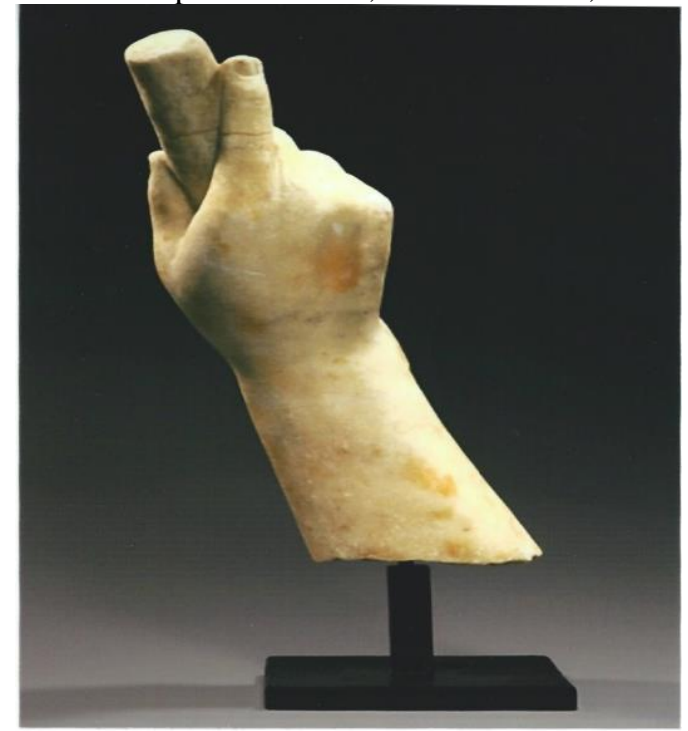

${ }^{1}$ I am working from my own digital photographs taken some time ago, so I cannot check the original Sarcophagus at this time; but it seems clear from the way the weapons are held, positioned, and raised to strike that they were never meant to be finished as swords or are broken pieces of spears (which would also not make sense since it is only the two leading officers using them). 
to fashion them into swords. They also cannot be unique to Pompilius and his lieutenant. There is, for example, at least one cavalryman depicted on the Column of Marcus Aurelius who appears to be holding another of these (broken) Truncheons upright in one hand (Figure 8). They must have been much more widely used by horse soldiers than previously known-- as lethal battering weapons as they rode though swarms of barbarians while busting heads. In the Sarcophagus sculpture, there even seems to be coordination between a Roman foot soldier in segmentata with oval shield who appears to be moving purposefully along side Pompilius to finish off any German not killed before he can recover from the blow of the general's Truncheon. The soldier is directly below his general's horse and is slashing the neck of a fallen opponent (Figure 1). This "Hammer and Slash" type of strategy, as we might describe it, would appear to be a recognized way of engaging a clustered enemy-- a coordinated offensive and defensive effort between cavalry and foot soldiers (much like the coordination of a tank and its assigned foot soldiers in World War II) which grew out of the Roman's experience of fighting barbarians in the dense forests along the Danube. Such tactics would also help frustrate the German horse stabbers and hewers mentioned by Speidel.

Figure 8. Cavalryman (Left Center) on the Column of Marcus Aurelius Holding Upright (Top Broken) what Appears to be another Example of a "Battle Truncheon"

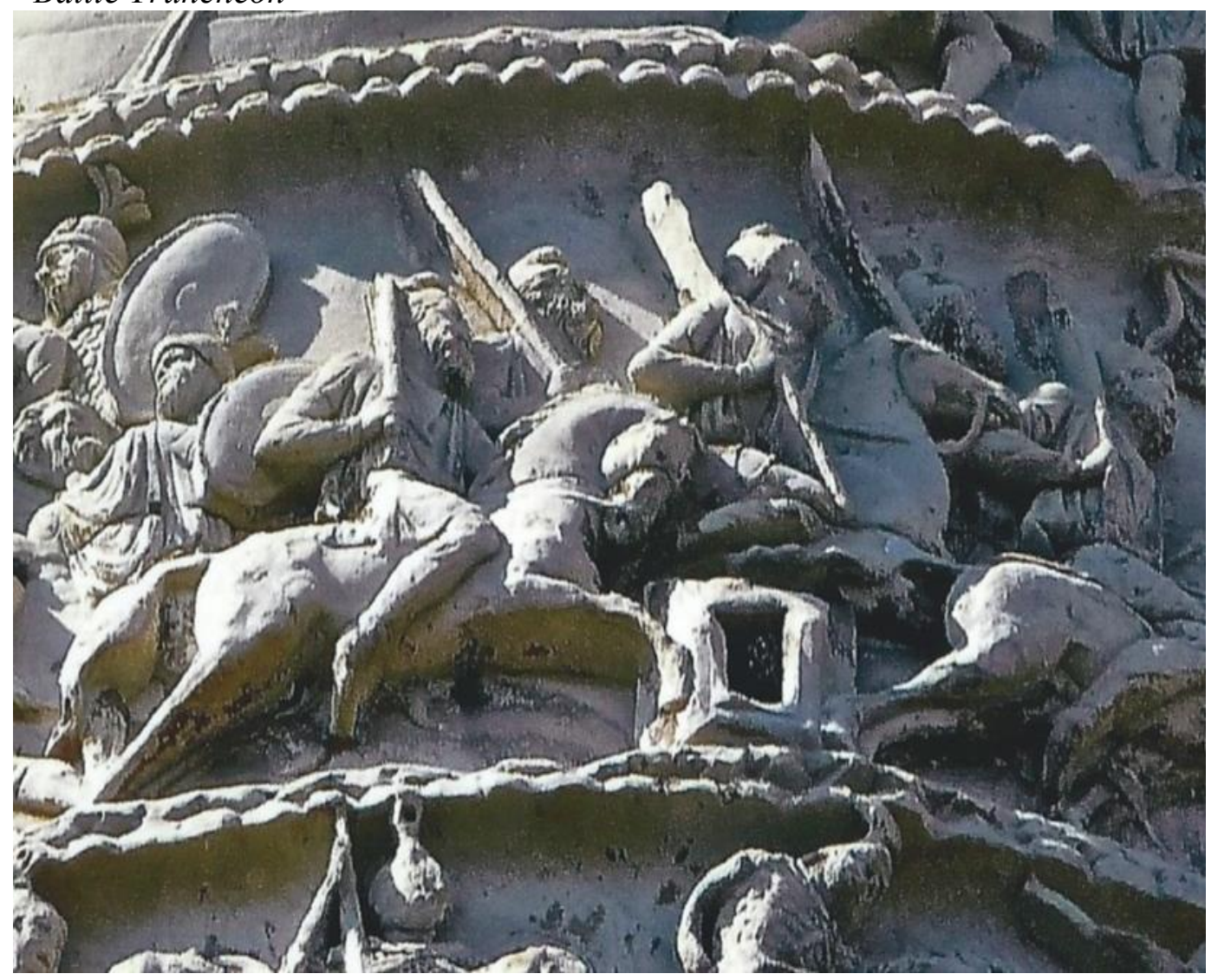


When Constantine later employed something of the same tactical concept of club warfare so effectively against Maxentius' heavy cavalry in different circumstances at Turin, the idea could not have been a new one. Clubs have been used since the beginning of human conflict, and, unquestionably, soldiers in mail armor employ the more basic version of clubs on the Aurelian Column. ${ }^{1}$ Such a weapon can be modified to the user's whim, so it should not be surprising to find sophisticated versions in the form of these "Battle Truncheons" in the hands of Pompilius and his lieutenant. ${ }^{2}$

Swords, lances, and arrows are more dramatic than soldiers in armor on horses going around bashing enemy heads. Perhaps the weapon never earned the "respect" the other more glorified ones did since, even today, nightsticks, or "billy cubs", hardly inspire romantic images. They are mostly associated with police, thugs, and riots. It may be that the only reason we see the "Battle Truncheon" at all on the Portonaccio Sarcophagus is that it was the favorite weapon of the general for whom it was being crafted-- and simply could not be omitted.

The Portonaccio Sarcophagus relief is also instructive for the kind of weather in which conflicts such as the one portrayed are fought; for the military attire of the Romans involved-- including that of a general; and for the attention given to the Germans, who are not rendered stereotypically as might be expected but more as individuals in their expression, dress, and weapons.

The Romans in the Sarcophagus battle all wear short sleeves. Some Germans are even bare from the waist up (similar examples appear on the Column of Marcus Aurelius). The battle is taking place, as would be expected, in a more temperate setting. Campaigns usually did not begin until March when the weather started to change. Heavy winter dress is just not suitable for the rapid movements of a cavalry charge-- nor could horses hold the ground on frozen or partially frozen turf. ${ }^{3}$ There are downed and rearing horses in the Portonaccio relief-- and the weather is good.

\footnotetext{
${ }^{1}$ Giovani Becatti, Colonna di Marco Aurelio (Milano: Editoriale Domus, 1957), Nos. 64-66.

${ }^{2}$ This was not only a more efficient way of disabling and killing an enemy, but it was also much "safer" for Roman troops fighting in close quarters. Razor sharp spathas and gladii, and lance heads indiscriminately slashing or pointed everywhere potentially could injure Roman cavalry, horses, and soldiers instead of the enemy. A blunt, metal tipped Truncheon is also more likely to hit some body part with a full downward swing because it does not have to be aimed as precisely, and the body language of Pompilius and his lieutenant already appears to demonstrate their confidence in doing great damage to those below. The Truncheon was also designed for fighting from a horse, and if a cavalryman were killed or disabled and dropped the weapon, it would have been much more difficult (than a sharp spatha or lance which would draw blood from any hit) for an enemy to pick up and fight upward against a charging horse and cavalryman. Such Truncheons would also be a more useful weapon in cold climates, since they could not freeze up. They certainly would have been less expensive and easier to make along the Danube, where resources were not so available to replace lost swords and lances. It seems a more practical weapon for use in the woodlands of Europe, and though the evidence is scanty, its employment must have been widespread.

${ }^{3}$ Dio, Roman History 71.7.1-5, illustrates why the Romans did not fight in winter when he reports a spontaneous battle between the Jazyges (Sarmatians) and Marcus Aurelius' troops on the frozen Danube, probably in 173 or 174 A.D. The Jazyges thought they could catch pursuing Romans by surprise on the ice, where they believed they would have the advantage. However,
} 
Pompilius' cavalry companions are arrayed in a variety of armors and helmets. On the Sarcophagus, lorica segmentata is apparent on only one foot solider in the foreground-- but he has a small oval shield rather than the full rectangular one usually seen. One cavalryman (perhaps two) also wears the same style. At least two others wear scale (squamata); and the rest wear cloaks making it difficult to determine their armor type. However, judging from their "decorative jagged fringe" short sleeves, they are wearing mail (hamata) because soldiers on the Aurelian Column (and Trajan's Column) wearing mail have that same type of pointed, short sleeve pattern. What seems to be the case here is that actual Roman cavalrymen wore armor most appropriate for the kind of fighting they did - and the favored style was not a form of segmentata. On the Column of Marcus Aurelius, there are as many soldiers and cavalrymen (perhaps more) not wearing as wearing segmentata.

General Pompilius is outfitted, as one would expect, in a manner that distinguishes him from everyone else. His horse also has a chest decoration. Whether or not someone like Pompilius would actually have gone into battle in such full regalia cannot be known. The idea was to survive by using the most efficient fighting gear - not to look good. Generals were also not usually in the thick of things, but this was, after all, to be an eternal representation of Pompilius on his Sarcophagus, so he would want to be shown in all his glory. His presence even seems to overwhelm his horse, which looks almost too small to support his splendorous master. Be that as it may, he still represents the way in which a general would be dressed (on or off the field) at this time.

Pompilius wears a cuirass with some decoration and anatomical features. He also wears a general's battle cloak, which is anchored at the right shoulder and folds loosely around his neck to the other side. His general's belt is tied round his waist. He is in short sleeves and wears leggings-- although it is unclear whether Pompilius has any lower leg armor protection. If he does, it does not extend up to his knee. Generals needed to be distinguished, and the plume on Pompilius' helmet is a very elaborate one. It has a metal crest with stylized feathers imprinted on it (unless they are meant to be actual feathers but too difficult for the sculptor to depict individually without the risk of them being broken off) and a very substantial plume flowing out the back and down his neck to his shoulders. It probably could not be much more elaborate without getting in the way.

For visual comparison, we include a representation of Pompilius on the Sarcophagus relief, and two other examples of generals from this same period (Figures 9-11). One of the latter stands next to Marcus Aurelius in the relief previously cited that represents the emperor on horseback showing his clemency to barbarian leaders (Figure 3) - so there can be no question about

the experienced Romans did not panic and quickly devised innovative ways to fight on the ice and stop the barbarian advance. The barbarians found they were no better off than the Romans in such conditions, and the ingenuity of the latter in handling the situation proved superior to the surprised barbarians, whose men and horses lost their footing and were pulled down. Dio treats the entire affair as an oddity, even a curiosity, which makes it clear such battles in winter were rare and impractical. Cf. Birley, Marcus Aurelius, 177. 
what a contemporary general looked like. He also holds a lance as a symbol of his authority and is very close both in dress and weapon to a representation of the emperor on the Aurelian Column, where Marcus is also facing barbarian captives. ${ }^{1}$ As the photos show, there are similarities among all the generals' outfits.

Figures 9-11. General's Dress of Pompilius, and one of Marcus Aurelius' Generals Standing Next to Him in the "Imperial Clemency Relief" (Also, Figure 3). The Latter General's Costume is so Close (Save For The Footwear) to that which Appears on the Contemporary Torso (Also Displayed in the Palazzo Massimo Museum Near the Portonaccio Sarcophagus) in Figure 11, that the Original Figure May Have Been of The Same Man

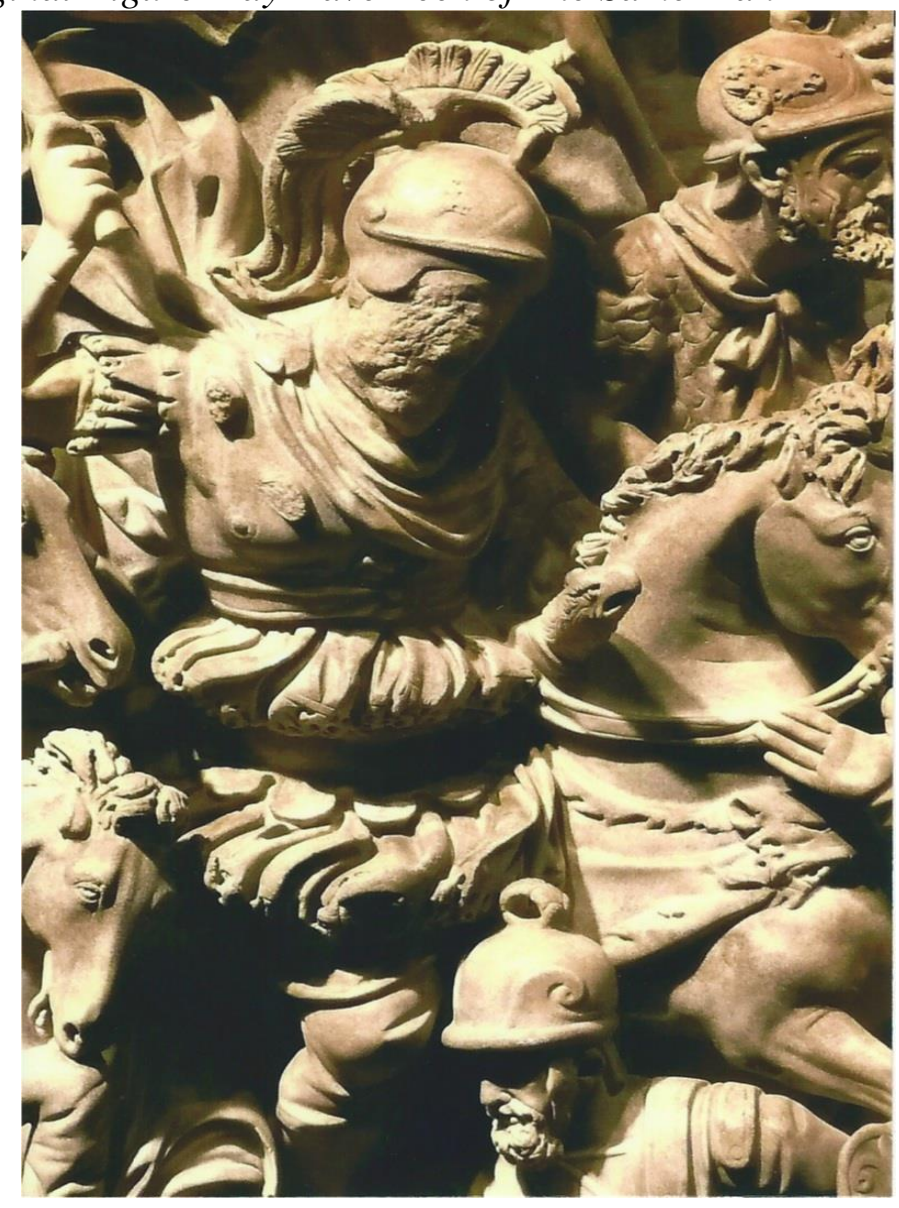

\footnotetext{
${ }^{1}$ Becatti, Colonia, No.15. In this scene, as well as many on the Column of Marcus Aurelius and other reliefs (for example, Figures 3 above and 10 below), it is clearly shown how the real Marcus Aurelius dressed both formally and less formally as emperor.
} 


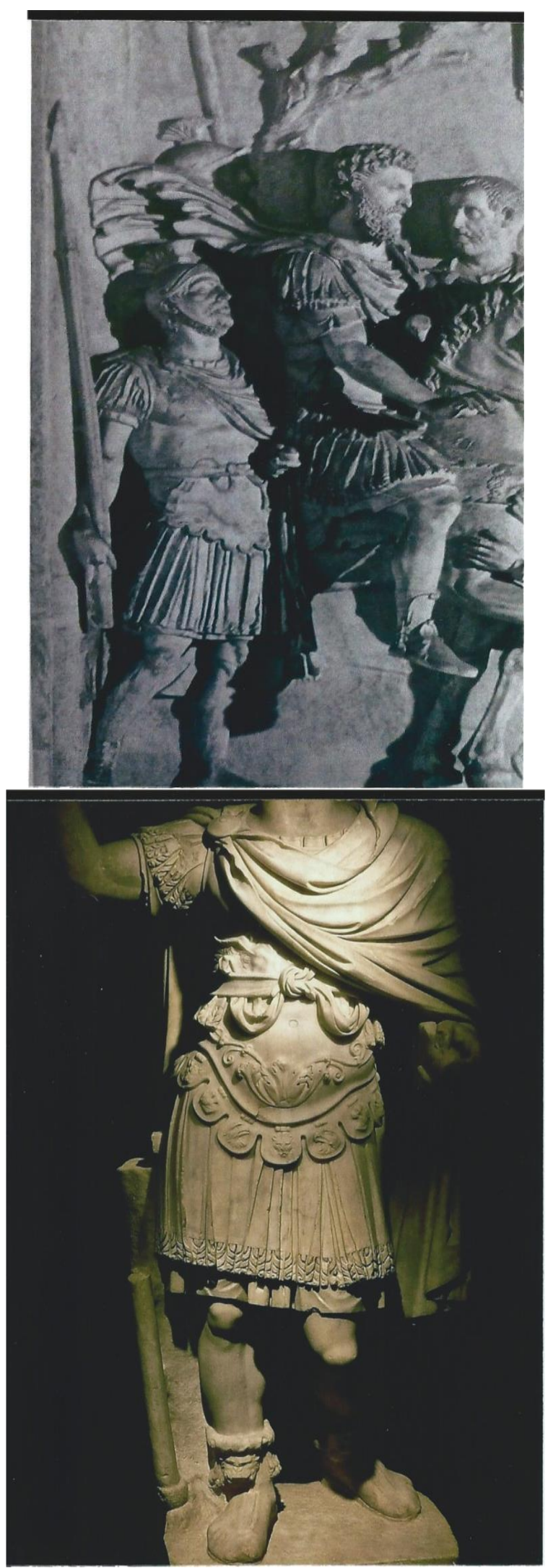


To conclude, while the relief on the Portonaccio Sarcophagus is symbolic and designed to celebrate a champion of Rome (expressing its domination in the slaughter of the Germanic barbarians), it, nonetheless, may be regarded as one of the most revealing representations of the Roman cavalry in action at this time. Despite limited space and artistic liberties, the general features of the Roman cavalrymen, their weapons, their horses, how they and their accompanying infantry fought their enemies, and the barbarians themselves, cannot simply be made up. The scene may be accepted as a mostly accurate portrayal. Consequently, everything would indicate that the "Battle Truncheons" and "Hammer and Slash" type of warfare seen on the Portonaccio Sarcophagus were standard Roman tactics in close quarter combat against barbarians on the Danube frontier.

The Portonaccio Sarcophagus also provides a valuable postscript for the stirring cavalry battle scene in Gladiator, arguably the most influential film about Rome in a generation, in the form of a corrective. There is little about the Roman contest on the Sarcophagus that bears any resemblance to Maximus' dramatic charge in the film. That movies are not historically accurate is a given; that modern audiences who view them think that they are, is also true. An artifact like the Portonaccio Sarcophagus offers a convenient opportunity to make a comparison between actual history and celluloid fiction- never an unprofitable exercise. In this case, new evidence emerged from this process about previously unrecognized aspects of the Roman military that would not otherwise have come to light.

\section{Bibliography}

Ancient

Cary, Earnest. trans., Dio, Roman History. Loeb Classical Library. Cambridge, Mass.: Harvard University Press, 1955.

Nixon, C.E.V., and Barbara Saylor Rodgers, eds., Panegyricie Latini. In Praise of Later Roman Emperors: The Panegyrici Latini, Berkeley and Los Angeles: University of California Press, 1994.

David Magie, trans., Scriptores Historiae Augustae (Augustan History). Loeb Classical Library. Cambridge, Mass.: Harvard University Press, 1967.

Rolfe, John C. trans., Ammianus Marcellinus. Loeb Classical Library. Cambridge, Mass: Harvard University Press, 1963.

\section{Modern}

Birley, Anthony. Marcus Aurelius: A Biography. New Haven and London: Yale University Press, [revised edition] 1987.

Becatti, Giovani. Colonia di Marco Aurelio, Milano: Editorale Domus, 1957.

Anonymous. Gladiator: The Making of the Ridley Scott Epic. New York: New Market Press, 2000.

Connolly, Peter. Greece and Rome at War. London: Greenhill Books, 1998 edition. 
Goldsworthy, Adrian. The Complete Roman Army. London: Thames \& Hudson Ltd., 2003.

Keppie, Lawrence. The Making of the Roman Army: from Republic to Empire. New York: Barnes \& Noble Books, [reprint] 1994.

Speidel, Michael P. Ancient Germanic Warriors: Warrior Styles from Trajan's Column to Icelandic Sagas. London and New York: Routledge, 2004.

Vogel, Lise. The Column of Antoninus Pius. The Loeb Classical Monographs Cambridge, Mass: Harvard University Press, 1973.

Webster, Graham. The Roman Imperial Army of the First and Second Centuries A.D. Totowa, N.J.: Barnes \& Noble Books, [Third edition], 1985.

Winkler, Martin. ed., Gladiator: Film and History. Oxford: Blackwell Publications Ltd., 2004). 
